Observations on Sporophyte Development in Odontoschisma prostratum (Hepaticae)

S. Rob Gradstein 


\title{
Observations on Sporophyte Development in Odontoschisma prostratum (Hepaticae)
}

\begin{abstract}
Anatomical study of developmental stages of the sporophyte of living Odontoschisma prostratum (Sw.) Trev. revealed that the conspicuous swelling of the female branch during sporophyte development is correlated with a remarkably strong growth of the sporophyte foot. Thus, the enlargement of the female branch must not be looked upon as a "perigynium precursor." The anatomy of the seta supplies new evidence for a close taxonomic relationship between Odontoschisma Dum. and Cladopodiella Buch.
\end{abstract}

Our knowledge of sporophyte development and shoot-sporophyte relationship in the liverwort genus Odontoschisma Dum. (Odontoschismataceae) is very incomplete. Up to now the only data available are a short description and an illustration of a longitudinal section of a female branch with juvenile sporophyte of Odontoschisma macounii (Aust.) Underw. by Evans (1903). In this picture, presented here in Fig. 2, a conspicuous swelling of the apex of the female branch is shown. The foot of the juvenile sporophyte together with a portion of the seta penetrate into the swollen branch which, according to Evans (1903, p. 334), is largely composed of food-storing cells. The capsule and the remainder of the seta are covered by the perianth and a thin calyptra, at the base of which a few unfertilized archegonia and slime-hairs are present. Except for the swelling of the female branch, the shoot-sporophyte relationship in O. macounii thus agrees with the "simple type" (type 1, Knapp, 1930) which is very common in the Jungermanniales. The swelling has been interpreted by Evans (1903) and also by Schuster (1966) as an initial stage of perigynium development, a "perigynium-precursor." Most hepaticologists have since treated the presence of this perigynium-precursor as a generic characteristic of the genus Odontoschisma Dum. Traditionally being considered a member of the family Cephaloziaceae, the genus was set aside in a separate family, Odontoschismataceae, by Mueller (1956).

It may be clear that for a proper evaluation of the taxonomic position of the genus Odontoschisma, comprising about 16 species in most of which the sporophyte is still unknown, a better knowledge of the sporophyte development is needed, if possible based on a histological study of all the developmental stages. My observations do not represent such a study, yet may supply some useful additions to the knowledge of the shoot-sporophyte relationship in Odontoschisma.

\section{Materuals and Methods}

During a short stay in Homochitto National Forest, Mississippi in March 1971, I collected (Gradstein 1611, v) fertile material of Odontoschisma prostratum (Sw.) Trev. with sporophytes in different stages of development. The plants were growing on the steep edge of a swampy spring along a small lake at Clear Spring Recreation Area, forming dense mats with Pallavicinia lyellii (c.sp.) and other bryophytes. In the laboratory the development of the sporophyte was studied by means of hand-sectioning of living plants. Additional data were obtained from collections of $O$. prostratum, $O$. sphagni, and $O$. denudatum in the herbarium of Dr. Margaret Fulford. Drawings were made with the aid of a Wild-Heerbrugg drawing apparatus.

\section{Observations}

The gynoecium of Odontoschisma prostratum occupies a very short Bazzania type of branch, thus originating ventro-intercalary on the stem from the axil of a reduced 

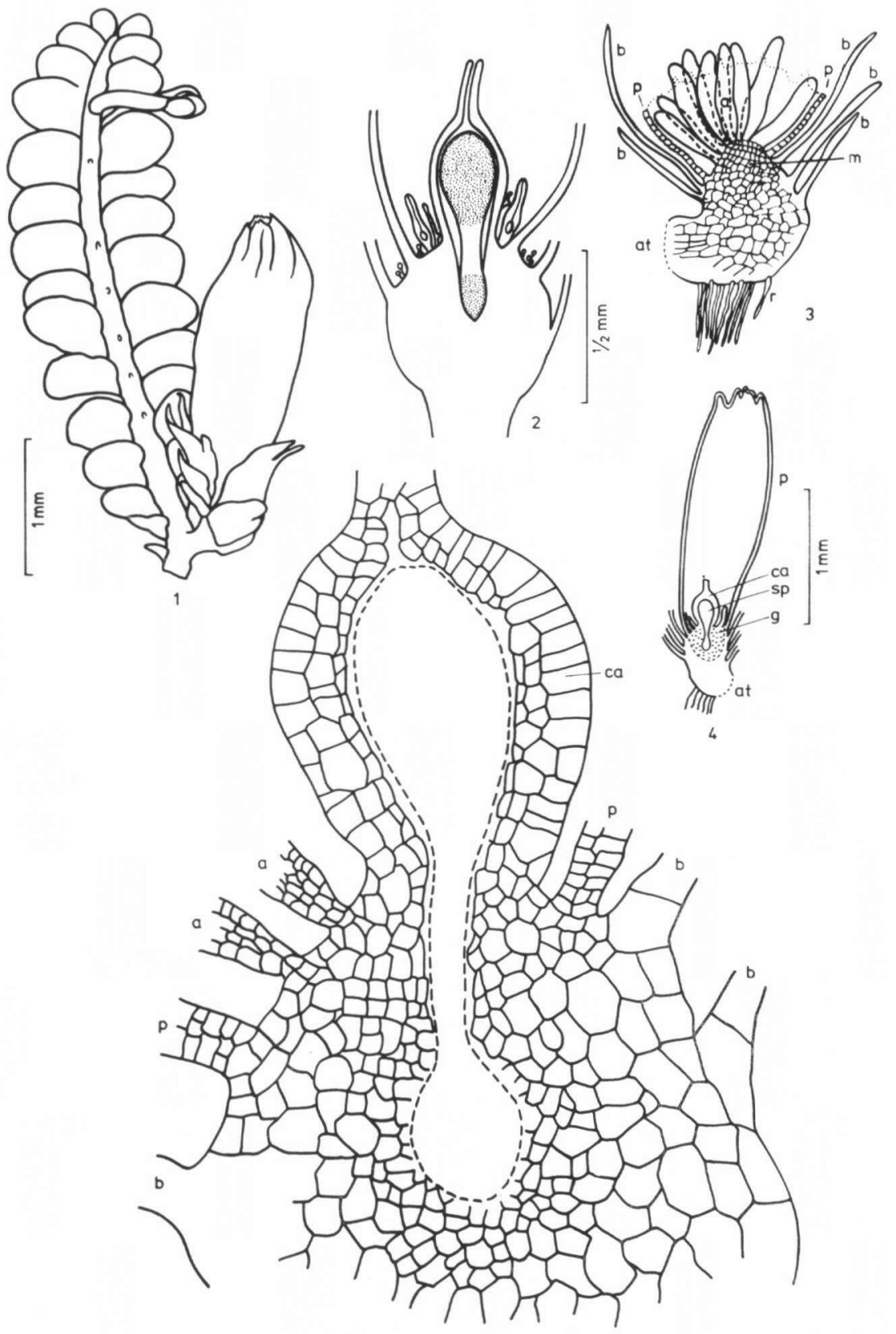

Figures 1-5. Odontoschisma prostratum and O. macounii. - 1. O. prostratum, stem bearing female branch and sterile branch (ventral view). - 2. O. macounii, longitudinal section through female branch and young sporophyte (somewhat diagrammatic). $-3-50$. prostratum, longitudinal sections through female branch. -3 . Before fertilization; $a$, archegonium; at, place of attachment of female branch to stem; $b$, bract; $m$, embryonic tissue; $p$, 
underleaf (Fig. 1). At the ventral base of the female branch a dense bundle of rhizoids is present. From its ventral insertion the branch curves almost straight upwards, giving the apex of the branch, which bears the archegonia, a dorso-lateral position. This position of the archegonia favours a positive phototropic growth of the sporophyte. At maturity the 9-10 archegonia are surrounded by 3 pairs of bifid bracts and bracteoles and a juvenile perianth, the crenate-ciliate mouth of which just reaches the top of the archegonia (Fig. 3). The archegonia are rather short and plump, the venter being scarcely wider than the short neck. In transverse section the neck consists of a ring of 5-6 outer cells surrounding the narrow canal (Fig. 10a). The axial tissue just below the archegonia consists of small, regularly arranged cells (Fig. $3 m$ ). Since the fundamental studies of Goebel on sporophyte development in the Jungermanniales, these cells are generally believed to be of embryonic nature (Knapp, 1930, p. 94).

After fertilization the perianth elongates rapidly, its mouth becoming rather deeply cleft. Near the base, the perianth becomes 2-3-stratose (Fig. 5, 10). The calyptra in $O$. prostratum seems to originate from archegonial tissue almost exclusively. At maturity, the calyptra is mainly 1-stratose except for the lower part surrounding the seta, where 3(-6) layers of cells are seen in transverse section (Fig. 10). In the juvenile sporophyte (Fig. 4-5), only the capsule is surrounded by the calyptra. The foot and the seta have become embedded in the apex of the branch. The female branch at this stage of development is distinctly enlarged, both in length and width. This enlargement must be due to cell division and elongation in the embryonic tissue. The juvenile foot and seta are surrounded by a narrow space filled with a mucilaginous substance and by a zone, 4-6 cells wide, of small axial cells (Fig. $4 \mathrm{~g}, 5$ ). Besides for their size, these cells are distinguished from the cells of the outer axial tissue by the presence of numerous granulae in the cell lumen and the virtual absence of chlorophyll and oil-bodies. In the juvenile sporophyte and calyptra oil-bodies appear to be lacking too.

During further development of the sporophyte the foot enlarges conspicuously, becoming suborbicular in outline (Fig. 6). A distinct collar surrounds the base of the seta which has emerged from the branch. The presence of a tail at the base of the foot could not be ascertained. Large bulging cells are seen at the outer side of the foot (Fig. 7). These cells may function as resorption cells. The strong growth of the foot causes a further swelling of the branch as can be understood from the cell arrangement in the outer axial tissue (Fig. 7). The curved lines into which these cells now have become arranged suggest a strong mechanical pressure from the expanding foot upon the branch. Elongation of the outer axial cells has taken place too.

When the sporophyte has matured, the foot occupies about half the volume of the female branch (Fig. 8). Downwards, the foot reaches just beyond the insertion of the lowest bracts and is separated from the ventral base of the branch by 5-6 rows of cells only. The tissue of small cells surrounding the foot has now become reduced, the intermediate space still being present. Figure 9 shows that in Odontoschisma denudatum a similar growth of the foot has taken place.

$\leftarrow$

perianth; $r$, rhizoid, $\times 65$. -4 . After fertilization, with young sporophyte; at, place of attachment of female branch to stem; $c a$, calyptra; $p$, perianth; sp, sporophyte. -5 . Young sporophyte (detail of Fig. 4); $a$, archegonium; $b$, bract; $c a$, calyptra; $p$, perianth, $\times 270$. Figures 1-2 after Evans (1903); 3-5 from Gradstein 1611 (U). 

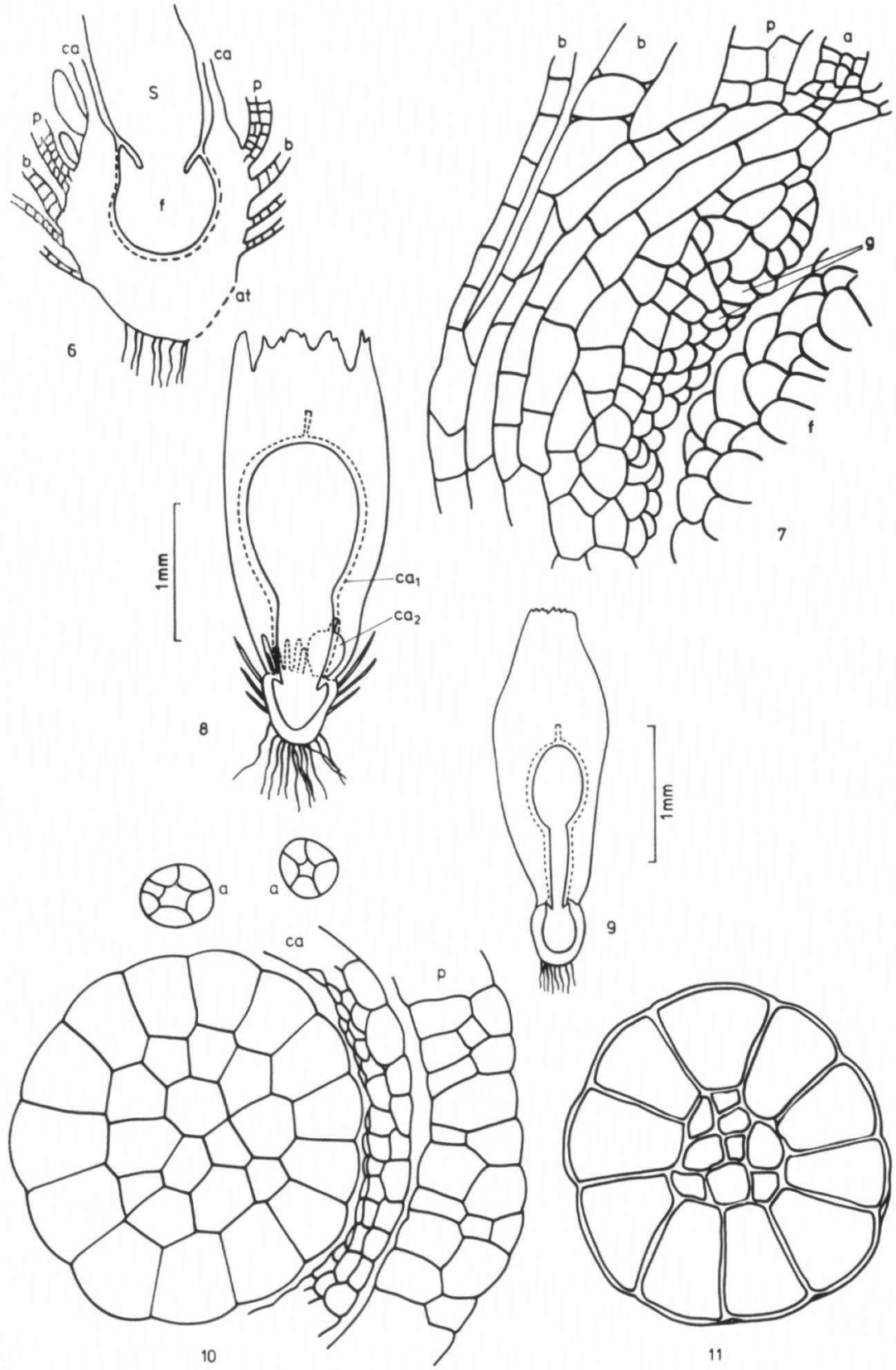

Ficures 6-11. Odontoschisma prostratum and 0 . denudatum. - 6-8. O. prostratum, longitudinal sections through developing sporophyte. - 6. Expanding foot; $b$, bract; $c a$, calyptra; $f$, foot; $p$, perianth; $S$, seta, $\times 65$. -7 . The same showing in detail bulging outer cells of foot and axial tissue pressed outwardly; $a$, archegonium; $b$, bract; $f$, foot; $g$, small axial cells, their lumens filled with granulae; $p$, perianth, $\times 270$. -8 . Mature sporophyte; $c a_{1}$, calyptra of mature sporophyte; $c a_{2}$, young calyptra resulting from fertilization (?) of another arche- 
The mature seta averages $200 \mu$ in diameter before elongation, being surrounded by the thickened lower part of the calyptra and the perianth (Fig. 10). In transverse section the seta is composed of a group of hyaline cells surrounded by one layer of larger, green cells. In all cells the walls are slightly thickened. The number of cells in the mature seta varies. In the two setae studied (Fig. 10-11), 14 outer and 13 inner cells, and 10 outer and 9 inner cells, were counted. The 14:13 arrangement might be less representative since this seta was cut fairly well down near its base.

The mature capsule of $O$. prostratum is oval-oblong in outline. The wall is 2stratose with the outer layer about $2 \times$ wider than the inner layer. The spores and elaters are rather irregularly arranged. The spores measure $14-15 \mu$. In general the capsule matches the generic descriptions by Evans (1903) and Mueller (1956).

\section{Discussion and Conclusions}

The shoot-sporophyte relationship in Odontoschisma prostratum agrees with Knapp's (1930) type 1 (= Jungermannia type, Schuster, 1966). The enlargement of the female branch at an early stage of sporophyte development, although conspicuous, is less pronounced than in $O$. macounii. At this stage of development the enlargement seems to be due to meristematic activity in the upper part of the female branch. This activity has been observed in many families of Jungermanniales, even in the Jubulaceae in which the sporophyte does not penetrate the female branch (Stotler \& Crandall, 1969). During further development of the sporophyte a subsequent swelling of the female branch in Odontoschisma occurs, caused by the pressure of the strongly expanding foot. The ultimate enlargement of the female branch thus must be looked upon as the result of both the meristematic activity in the branch and the growth of the foot. Physiologically there seems to be a functional relation between the large size of the mature foot and the strong meristematic activity. In my opinion, there are no good reasons to assume that this enlargement of the female branch should be considered an initial stage of perigynium development since the axial tissue apparently is not elaborated for the protection of the mature seta and the capsule.

The seta in the genus Odontoschisma, according to Mueller (1956), is of the Cephalozia type, consisting of 8 outer cells and 4 inner cells, all of the same size. My observations show that in $O$. prostratum a different type of seta is present. The cells are more numerous and the outer cells are larger than the inner cells. This type of seta can be considered to be derived from the Cephalozia type by secondary cell divisions and is also known in Cephalozia bicuspidata (Douin, 1916) and in the genus Cladopodiella Buch (Mueller, 1956). The close taxonomic relationship between the genera Cladopodiella and Odontoschisma, noted as early as 1882 by Spruce and underlined, i.a., by Evans (1903) and Fulford (1969), thus becomes more evident. The shootsporophyte relationship in Cladopodiella and other genera related to Odontoschisma, such as Anomoclada Spruce and Alobiellopsis Schust., still remains a subject for investigation.

$\leftarrow$

gonium. - 9. O. denudatum, longitudinal section through mature sporophyte. $-10-11 . O$ prostratum, anatomy of the seta. - 10. Transverse section through basal part of seta, calyptra, perianth, and some unfertilized archegonia (somewhat diagrammatic); $a$, archegonium; $c a$, calyptra; $p$, perianth, $\times 270$. - 11. Transverse section through middle of seta, $\times 270$. Figures 6-8, 10-11 from Gradstein 1611 (U); 9 from Schiffner, Hep. Eur. Exsicc. 578 (herb. Fulford). 
This study was made when I was a graduate research assistant of Dr. Margaret Fulford at the University of Cincinnati. I am very grateful to Dr. Fulford for the use of her library and herbarium and for the numerous stimulating discussions. Mr. T. Schipper of the State University of Utrecht skillfully prepared the drawings for reproduction. I thank Dr. William D. Reese and his wife for their warm hospitality and for guiding me to the collecting site of Odontoschisma prostratum.

\section{Literature Cited}

Dourv, Ch. 1916. Le pédicelle de la capsule des Hépatiques. Rev. Gén. Bot. 28: 129-132. Evans, A. W. 1903. Odontoschisma macounii and its North-American allies. Bot. Gaz. 36: $321-348$.

Fulford, M. 1969. Manual of the leafy Hepaticae of Latin America-Part III. Mem. New York Bot. Gard. 11: 277-392.

KNAPP, E. 1930. Untersuchungen über die Hüllorgane um Archegonien und Sporogonien der akrogynen Jungermanniaceen. Bot. Abhandl. 16: 1-168.

Mueller, K. 1956. Die Lebermoose Europas. VI. Band, in Rabenhorst's Kryptogamen Flora, 3rd ed. 6: 1077-1220.

Schuster, R. M. 1966. The Hepaticae and Anthocerotae of North America East of the Hundredth Meridian. Vol. 1. New York.

Spruce, R. 1882. On Cephalozia, Its Subgenera and Some Allied Genera. Malton.

Stotler, R. E. \& B. J. Crandall. 1969. The sporophyte anatomy of Dicranolejeunea axillaris. The BhYoLogist 72: 387-397.

S. Rob GradsteIn, Instituut voor Systematische Plantkunde, Transitorium II, Uithof, Utrecht, The Netherlands. 